\title{
Reo-like virus in white shrimp Penaeus vannamei (Crustacea: Decapoda): co-occurrence with Baculovirus penaei in experimental infections
}

\author{
Rena M. Krol, William E. Hawkins, Robin M. Overstreet \\ Gulf Coast Research Laboratory, PO Box 7000, Ocean Springs, Mississippi 39564, USA
}

\begin{abstract}
A virus, tentatively identified as reo-like, occurred concurrently with experimentallyinduced Baculovirus penaei (BP) infection in cultured white shrimp larvae Penaeus vannamei. Each shrimp with a reo-like viral infection also had a BP infection, but not all BP-infected shrimp had a reolike infection. Both viruses occurred in the same tissues and occasionally within the same cell. The reolike virus developed in epithelial cells of the anterior midgut and in reserve-and fibrillar-cells of the hepatopancreas. The paraspherical and non-enveloped reo-like virions (ca $50 \mathrm{~nm}$ diam.) occurred as unordered aggregates in the cell cytoplasm. Their etiology has not been determined. Reo-like virions may have been introduced along with the BP virus, or, were latent and only manifested due to stress induced by the more pathogenic BP virus.
\end{abstract}

\section{INTRODUCTION}

Reo-like viruses have been reported in several species of crabs and shrimp. The paralysis virus of the portunid crab Macropipus depurator (Vago 1966, Bonami 1973, Bonami et al. 1976, Bergoin et al. 1982) and the reo-like virus of the blue crab Callinectes sapidus (Johnson \& Bodammer 1975, Johnson 1977. 1984), are associated with fatal paralysis of their hosts. In the Mediterranean shore crab Carcinus mediterraneus, a highly pathogenic, sometimes fatal, reo-like virus infecting the gill epithelium (Bonami 1977, Bergoin et al 1982), and a reo-like virus, of undetermined pathogenicity, infecting the hepatopancreatic epithelium (Mari \& Bonami 1987) have been reported. With regard to shrimp, reo-like virus appeared to have limited pathogenicity in the kuruma shrimp Penaeus japonicus (Tsing \& Bonami 1987). Nash et al. (1988) recently reported a reo-like virus in dying giant tiger shrimp P. monodon, but could not determine whether the virus was the cause of death. Most of these reo-like viruses occur along with other viral infections, or are associated with other diseases in the same host.

During studies on the effects of Baculovirus penaei (BP) in larval white shrimp Penaeus vannamei, we observed a second virus tentatively identified as a reolike virus in the midgut and hepatopancreatic epithelium. This reo-like virus occurred only in specimens infected with BP. Here, we report on the ultrastructure and cytopathology of this virus and its relationship to BP.

\section{MATERIAL AND METHODS}

Naupli stage Penaeus vannamei were purchased from a commercial hatchery. Approximately 150 larvae were placed in each of ten $1 \mathrm{l}$ Imhoff settling cones. When larval shrimp developed to the Protozoeal III stage, larvae in 5 of the cones were infected with BP virus. Larvae in the other 5 cones served as controls; they were not exposed to viral material and were maintained in a separate, virus-free room.

Details of experimental infection protocols have been reported elsewhere (Overstreet et al. 1988). Briefly, rotifers Branchionus plicatilis were fed minced larval shrimp tissues with microscopically confirmed BP infections. The BP-infected tissues had been collected from previous bioassays and stored at $-70^{\circ} \mathrm{C}$. Tissues were thawed and pulverized into a paste. Rotifers were exposed to the BP-infected tissues for 2 to $3 \mathrm{~h}$ and then fed to shrimps. After protozoeal shrimp were exposed to rotifers for $26 \mathrm{~h}$, rotifers and uneaten debris were removed and the water replaced. Both experimentally 
infected and negative control larvae were maintained in cones and fed a diet of brine shrimp Artemia salina.

Exposed and control larvae were examined by light and electron microscopy at 96, 117.5 and $142 \mathrm{~h}$ post shrimp-exposure. For electron microscopy, shrimp were cut into cephalothorax and tail portions and fixed in $2.0 \%$ glutaraldehyde in $0.025 \mathrm{M}$ sodium cacodylate buffered seawater. Specimens were postfixed in $1.0 \%$ osmium tetroxide in $0.1 \mathrm{M}$ sodium cacodylate buffer, dehydrated in a graded series of ethanols, and embedded in Spurr's resin (Spurr 1969). Specimens were oriented in flat molds so that cross-sections of cephalothorax could be examined for systemic viral infection. Ultrathin sections were stained with uranyl acetate and lead citrate (Reynolds 1963) and examined with a JEOL $100 \mathrm{SX}$ electron microscope at $60 \mathrm{KV}$.

\section{RESUITS}

Twenty-three shrimp, 14 experimentally infected and 9 negative controls, from 96, 117.5 and $142 \mathrm{~h} \mathrm{sam-}$ ples were examined by light and electron microscopy to determine the co-occurrence of $\mathrm{BP}$ and reo-like infections. Nine of 14 shrimp fed BP-infected material showed morphological evidence of BP infection and 5 of the 9 also contained reo-like virus. None of the 9 controls examined exhibited evidence of either virus.

Polyhedral occlusion bodies characteristic of BP infection, as well as free BP virions, were present in nuclei of epithelial cells of the hepatopancreas and anterior midgut of experimentally infected shrimp. The reo-like virus occurred as small clusters of virions in the cytoplasm of hepatopancreatic and anterior midgut epithelial cells (Fig.1). Occasionally, both viruses occurred in the same cell (Fig. 2). The reo-like virus most frequently infected reserve (R) cells and, to a lesser extent, fibrillar (F) cells of the hepatopancreas (Fig. 3). The virus occured as unordered aggregates of virions in a filamentous matrix which resembled a virogenic stroma. The virions were 40 to $60 \mathrm{~nm}$ in diameter, paraspherical, and non-enveloped (Fig.4). The outer shell of the virion appeared fragile and often lost its structural integrity.

\section{DISCUSSION}

Based on shape, size, and cytoplasmic location, the virus described here belongs to the family Reoviridae. Positive identification, however, depends on isolation, purification and analysis of its nucleic acid. The reo-

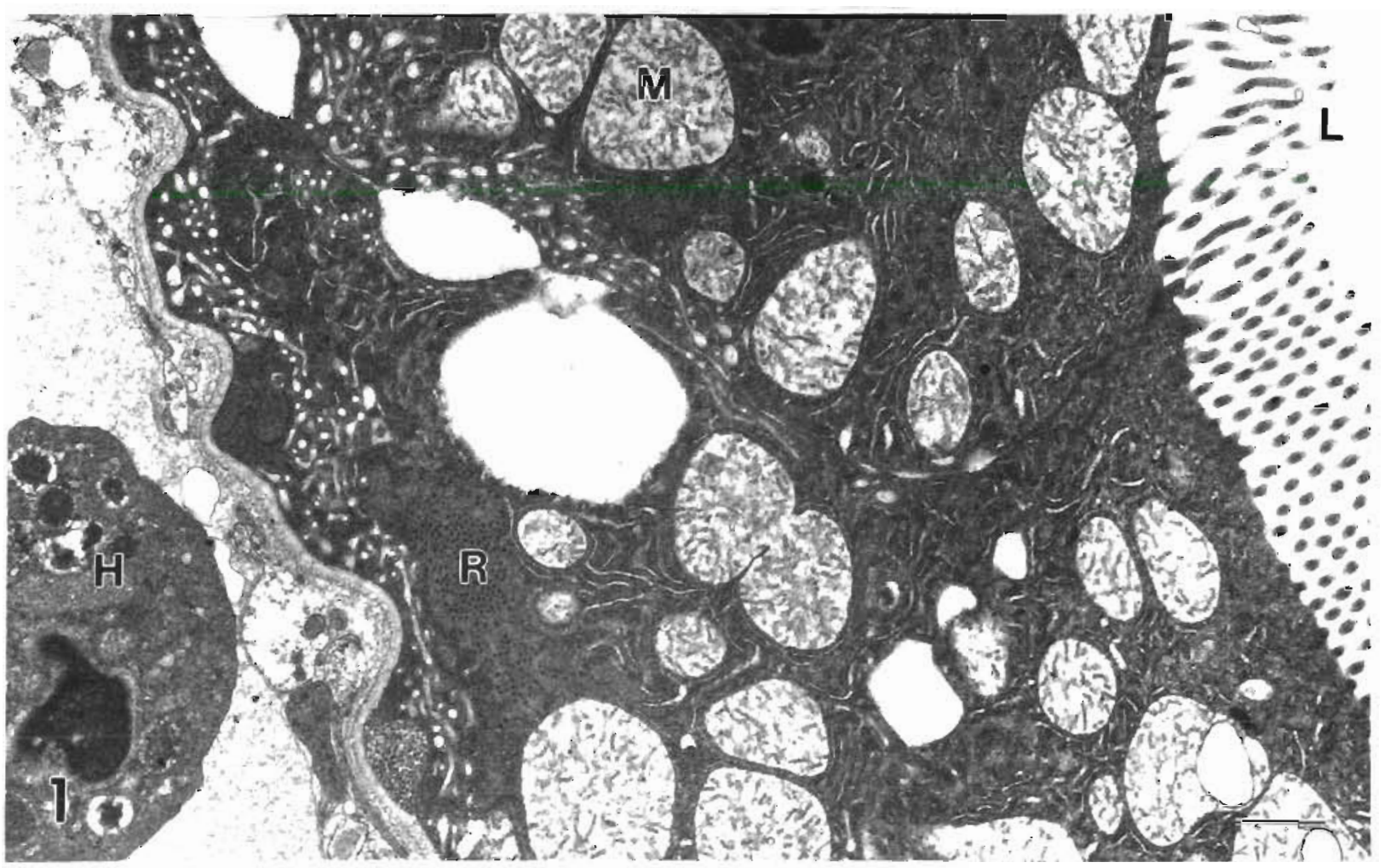

Fig. 1. Penaeus vannamei. Reo-like virus infection of anterior midgut epithelium. R: reo-like virions; $M$ : mitochondria $; L_{i}$ midgut tubule lumen; $\mathrm{H}$ : hemocyte. Bar $=1 \mathrm{um}$ 

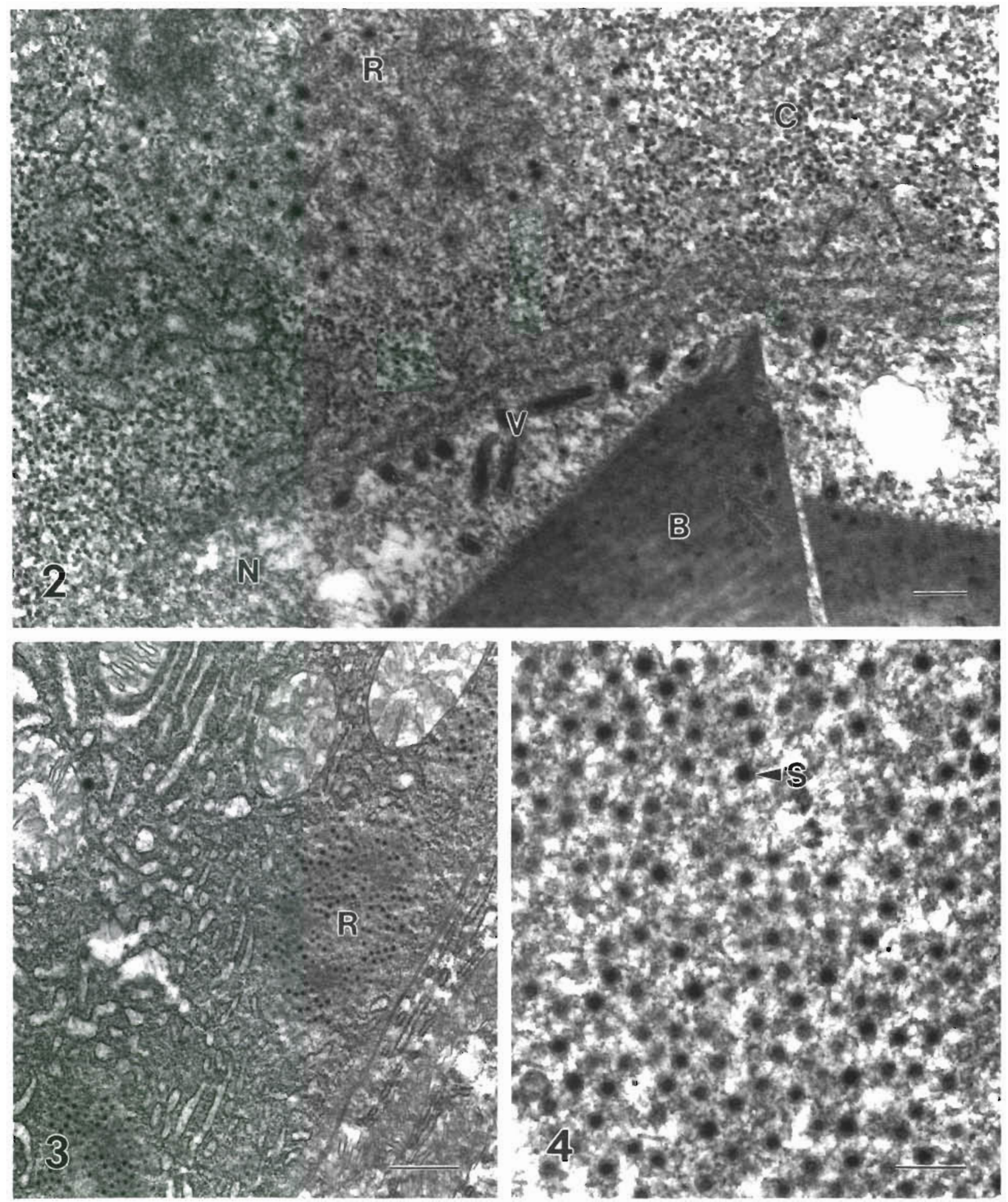

Figs. 2 to 4. Penaeus vannamei. Fig. 2. Concurrent BP and reo-like infections in hepatopancreas cell. R. reo-like vinons, B BP polyhedron with sequestered virions; $\mathrm{V}$. free BP vinons; N nucleus, $\mathrm{C}$ cytoplasm Bar $=200 \mathrm{~nm}$ Fig 3. Reo-like infectıon in Fcell of hepatopancreas; R: reo-like virons. Bar $=500 \mathrm{~nm}$. Fig. 4. Reo-like virions; S outer shell. Bdr $=200 \mathrm{~nm}$ 
like virus in Penaeus vannamei not only infected hepatopancreatic cells as did the reo-like viruses described in $P$. japonicus by Tsing \& Bonami (1987) and in P. monodon by Nash et al. (1988), but also epithelial cells of the anterior midgut. Virions in both $P$. vannamei and in $P$. japonicus occurred in unordered aggregates primarily in R- and F-cells (Sindermann \& Lightner 1988) in contrast with virions in $P$. monodon which sometimes occurred in paracrystalline arrays. The 40 to $60 \mathrm{~nm}$ diameter virions of $P$. vannamei were somewhat smaller than those in $P$. monodon $(50$ to $70 \mathrm{~nm}$ diam.) and in P. japonicus (61 nm diam.).

Several reo-like viruses infect crabs but only the RC84 virus of Carcinus mediterraneus resembles the reo-like viruses reported in shrimp (Mari \& Bonami 1987). The RC84 virus is restricted to the hepatopancreas, primarily in blister (B) cells, but also in R-cells in heavy infections. Like the reo-like virus in Penaeus vannamei, the RC84 virions are usually found in an unordered arrangement.

Examples of simultaneous viral infections with 2 or more viruses infecting the same organism have been reported in several crustaceans. An unidentified virus was found in a purified preparation of reo-like virus from Penaeus japonicus (Tsing \& Bonami 1987). Reolike viruses were associated with $P$. monodon baculovirus (Nash et al. 1988), with a bunya-like virus in Macropipus depurator (S-P syndrome) (Bonami 1973), with a picorna-like virus in the parasitic isopod Portunion conformis (Kuris et al. 1979), and with a virus in connective tissue of Carcinus mediterraneus (Mari \& Bonami 1987). Johnson (1984) considered rhabdo- and reo-like infections in the blue crab Callinectes sapidus to be synergistically pathogenic. That does not appear to be the case, however, with BP and the reo-like virus described in this report.

Although multiple viral infections of various tissues often occur in individual crabs, the co-occurrence of viral infections in digestive epithelium has not been reported (Mari \& Bonami 1987). This contrasts with the $\mathrm{BP}$ and reo-like infections in Penaeus vannamei which develop not only in the digestive epithelium of the same individual but occasionally in the same cell.

We cannot determine from this study whether the reo-like virus in Penaeus vannamei was introduced with Baculovirus penaei (BP) in experimental infections, or whether the reo-like virus was latent and appeared secondarily to stress brought on by the highly pathogenic BP. The presence of reo-like viruses in several other crustaceans, however, seems certainly to be related to stress, since the viruses usually occurred in organisms sensitive to other pathogens. Tsing \& Bonami (1987) suggested that the reo-like virus in $P$. japonicus may be a predisposing stress-factor leading to other disease conditions. For example, shrimp with reo-like infections were often infected with the imperfect fungus Fusarium sp. Because reo-like virus infections in $P$. japonicus often occurred in shrimp that otherwise appeared healthy, the virus probably was not pathogenic (Sindermann \& Lightner 1988). An experimental reo-like infection in $P$. japonicus developed slowly, with no mortalities occurring until $45 \mathrm{~d}$ post infection (p.i.) (Tsing \& Bonami 1987). The light infections of reo-like virus that we observed at 96 to $142 \mathrm{~h}$ p.i. were concomitant with heavy infections of $\mathrm{BP}$. Because BP is highly lethal to larval shrimp, with almost $100 \%$ loss of the population within 1 to $2 \mathrm{~d}$ of the appearance of infection (Overstreet et al. 1988, Sindermann \& Lightner 1988), it is likely that the reolike virus also exhibits a limited pathogenicity in $P$. vannamei because of its apparently slow developmental time.

Acknowledgements. We thank Mary Ann Vogelbein for her technical assistance and Dr Donald Lightner, University of Arizona, for his valuable comments on this study. This study was supported in part by U.S. Department of Agriculture, Cooperative State Research Service, Grant No. 88-38808-3319.

\section{LITERATURE CITED}

Bergoin, M., Bonami, J.-R., Morel, G. (1982). Crab and spider viruses. Proc. int. Colloq. Invertebr. Path. 3: 523-526

Bonami, J.-R. (1973). Recherche sur la paralysie virale du Crustacé Décapode Macropipus depurator L. Revue Trav. Inst. (scient. tech.) Pêch. marit. 37: 387-389

Bonami, J.-R. (1977). Les maladies virales des crustaces et des mollusques. Océanis, Paris 3: 154-175

Bonami, J.-R., Comps, M., Veyrunes, J.-C. (1976). Etude histopathologique et ultrastructurale de la paralysie virale du crabe Macropipus depurator L. Revue Trav. Inst. (scient. tech.) Pêch. marit. 40: 139-146

Johnson, P. T (1977). A viral disease of the blue crab, Callinectes sapidus: histopathology and differential diagnosis. J. Invertebr. Path. 29: 201-209

Johnson, P. T. (1984). Viral diseases of marine invertebrates. Helgoländer Meeresunters. 37: 65-98

Johnson, P. T., Bodammer, J. E. (1975). A disease of the blue crab. Callinectes sapidus, of possible viral etiology. J. Invertebr. Path. 26: 141-143

Kuris, A. M., Poinar, G. O. Jr, Hess, R., Morris, T J. (1979). Virus particles in an internal parasite, Portunion conformis (Crustacea: Isopoda: Entonsicidae), and its marine crab host, Hemigrapsus oregonensis. J. Invertebr. Path. 34: 26-31

Mari, J., Bonami, J.-R. (1987). A reolike virus of the Mediterranean shore crab Carcinus mediterraneus. Dis. aquat. Org. 3: $107-112$

Nash, M., Nash, G., Anderson, I. G., Shariff, M. (1988). A reolike virus observed in the tiger prawn, Penaeus monodon Fabricius, from Malaysia. J Fish Dis. 11: 531-535

Overstreet, R. M., Stuck, K. C., Krol, R. A., Hawkins, W E. (1988). Experimental infections with Baculovirus penaei in the white shrimp Penaeus rannamel (Crustacea: Decapoda) as a bioassay. J. Wld Aquaculture Soc. 19: 175-187 
Reynolds, E. S. (1963). The use of lead citrate at high pH as an electron-opaque stain in electron microscopy. J. Cell Biol 17: $208-212$

Sindermann, C. J., Lightner, D. V. (eds.) (1988). Disease diag nosis and control in North American marine aquaculture Developments in Aquaculture and Fisheries Science, Vol. 17, 2nd edn. Elsevier Science Publishers, The Netherlands

Responsible Subject Editor: Dr J. E. Stewart, Dartmouth, N.S. Canada
Spurr, A. R. (1969). A low viscosity epoxy resin embedding medium for electron microscopy. J. Ultrastruct. Res. 26 $31-43$

Tsing, A., Bonami, J.-R. (1987). A new viral disease of the tiger shrump, Penacus japonicus Bate. J. Fish Dis. 10: 139-141

Vago, C. (1966). A virus disease in Crustacea. Nature, Lond 209: 1290

Manuscript first received: July 4, 1989

Revised version accepted: December 1, 1989 